
\title{
Effects of Bank Lending on Economic Growth in
} Nepal

\author{
Neelam Timsina \\ Prof. Dr. Radhe Shyam Pradhan
}

\begin{abstract}
This study examines the effects of commercial bank lending on economic growth in Nepal. The study has conducted correlation and regression analysis using panel data of twenty four commercial banks during the period of 1996 -2015. The empirical results show that bank lending has positive effects on the economic growth in Nepal. The study implies that the policy makers should focus their attention more on the development of formal sector financing, adequate development of modern banking sector, development of efficient financial market and infrastructures and establishment of interest sensitive investment environment to increase the bank lending which is instrumental to promote economic growth in Nepal.
\end{abstract}

Key Words: Economic Growth, Bank Lending, Regression JEL Classification: E23, G21, C33 
ISSN: 2362-1303 (Paper) | eISSN: 2362-1311(Online)

JOURNAL OF ADVANCED ACADEMIC RESEARCH (JAAR) October 2016

\section{INTRODUCTION}

Macroeconomic policy of a country has several objectives. Out of them, economic growth is one of the major objectives. It is considered as the crucial way of uplifting living standard of people and promoting economic development. Lending is the sum of money provided by commercial banks to individuals, commercial corporations/industrial units and country's government for consumption and investment purposes in the expectation of repayment with interest. Commercial banks provide credit to individuals for both consumption and investment purposes, to commercial corporations/industrial units to invest in plant and machinery and to government for conducting recurrent and capital expenditure. Particularly, lending means the provision of resources such as providing a loan by the creditor/lender to the borrower with a condition to require debtor to reimburse the lender within a certain period, thereby generating a debt. (Mishra et al, 2009). Bank lending is considered as a key to economic growth especially in developing countries as it helps to lubricate the economy. Therefore, the researchers have consensus that the role of bank credit in economic growth is crucial as various economic agents are able to invest money in various investment opportunities via bank lending.

Also in Nepal, economic growth is considered as one of the major macroeconomic objectives. Nepal Rastra Bank (NRB), the central bank of Nepal considers that monetary policy should also support growth. Due to the lack of direct attachment between the monetary policy instruments (expected policy actions) and economic growth, the central bank has to resort on the coordination of commercial bank. By affecting the commercial banks' loanable fund/reserves via change in cash reserve ratio, bank rate or open market operation, and various regulatory directions, the central bank uses to support economic growth. Moreover, NRB always directs commercial banks to flow their credit to productive sector like agriculture, hydroelectricity, tourism and other industries. Bank lending channel of monetary policy is considered very important and effective in developing countries like Nepal. In this channel, monetary policy action is expected to affect real economic variables through the means of bank balance sheet and availability of bank lending. A wide body of literature advises that development of financial sector has a crucial role in economic development. Okwo (2012) examined the effect of bank lending to the private sector 
ISSN: 2362-1303 (Paper) | eISSN: 2362-1311(Online)

JOURNAL OF ADVANCED ACADEMIC RESEARCH (JAAR) October 2016

on economic growth in Nigeria and found that there is strong statistical positive impact of bank lending to private sectors to the GDP as expected. Bank credit to private sector through capital collection and technological innovations, promotes economic development by mobilizing and pooling savings at the increasing savings rate, generating information on investment, easing as well as motivating the foreign capital inflows, as well as optimizing the tribution of capital (World Bank, 2013). A major indicator for measuring financial development of an economy is the ratio of bank loan and advances to nominal GDP.

There are several studies that have been carried out on this topic in foreign countries but in case of Nepal there are not enough studies on this topic especially based on recent panel data and method. Thus, this study acts as the basis for further investigation in the area of bank lending and economic growth in Nepal. This study attempts to identify whether the bank lending affects economic growth. Thus the main objective of this study is to assess the effects of bank lending on economic growth as well as to suggest ways of imporving and expanding the bank lending to achieve better economic growth in Nepal.

The rest of the paper is structured in the following manner. The second section presents the theoretical framework. The third section reviews the related literatures. The fourth section presents the status and trend of economic growth and bank lending in Nepal. The fifth section describes the data and methodology and the sixth section shows the results of the study. The last section presents conclusion and recommendation.

\section{THEORETICAL FRAMEWORK}

Bank lending is the key to economic growth. Adedoyin and Sobodun (1996) said that lending is undoubtedly the heart of banking industries. Bank loans are one of the most important long-term financing sources in many countries (Freixas and Rochet,2008). Commercial banks are highly important savings mobilization and financial resources allocation institution. In due course, these roles lead them to play an important role in economic growth and development. In order to perform these roles, it must be understood that banks have the scope, potential and prospects of financial intermediation (Olokoyo 2011). Commercial banks perform the act of financial intermediary that gather money from the excess sector in the form of deposits and lend 
ISSN: 2362-1303 (Paper) | eISSN: 2362-1311(Online)

JOURNAL OF ADVANCED ACADEMIC RESEARCH (JAAR) October 2016

it to various sectors of the economy. Lending is one of the major functions of banking institution. Through this work, banks affect the economic growth and stability in the economy. Although credit growth can spur investment and economic activity, an excessive growth in credit can impact the price stability as well as stability of the financial system by increasing prudential risks at the micro and macro levels (Igan and Pinheiro, 2011).

Bank lending contributes to economic growth in several ways. Bank lending is an important link in money transmission; it finances production, consumption, and capital formation, which in turn promote economic activity. The transmission mechanism of monetary policy can be strengthened, and the objectives of monetary policy achieved to a great extent, especially if the banking system is well-operated and managed under certain regulation. Credit to the private sector in an environment of banking discipline will be instrumental in promoting productive possibilities and bright development scenario of the economy. It thereby leads to boost economic growth, creating employment, prospects and increasing the competitiveness of the economy (Basyal, 2009). It is a crucial means of generating and promoting self- employment opportunities, strengthening informal activities. Adimu (2006) asserted that bank lending can be utilized to restrict economic activities from total collapse in the event of natural disaster such as disease, draught, flood or fire. Through the use of credit, agricultural production can be increased by investing money in seed, tractor, fertilizers, pump set and other agricultural instruments. Industrial corporations can also increase industrial production by using credit. Moreover the role of credit is significant in burgeoning also the service sectors. Over all ingredients of GDP require bank lending to grow. In performing the role of financial mediator, it is believed that banks generate economic growth by providing required resources in various investment areas (Kinnon, 1973). High and sustained economic growth depends on the ability to raise the rates of accumulation of physical capital and accumulation and quality enhancement of human resources to use the resultant valuable assets effectively and to make sure the access of the entire population to these assets (Fitzgerald, 2006). Only access to bank credit can make it possible. As commercial bank does efficient financial intermediation and extension of credit is one of the major functions of banking institution, bank credit helps to promote economic growth. 
ISSN: 2362-1303 (Paper) | eISSN: 2362-1311(Online)

JOURNAL OF ADVANCED ACADEMIC RESEARCH (JAAR) October 2016

Labor and capital are the major factors of production. I.e. $Y=f(K, L)$ as per the Neoclassical growth theory, where $\mathrm{Y}$ denotes aggregate output, $\mathrm{K}$ denotes aggregate capital stock, and L denotes the labor-force. If technological innovations and human resources are added, then equation will be : Yi,t $=\mathrm{AK} \alpha(\mathrm{Lh}) 1-\alpha$. ( Mankiw, Weil and Romer,1992). Commercial bank lending facilitates to gain more capital in this production function. When a new technology is available, the labor and capital require to be adjusted to retain growth equilibrium. The role of commercial bank credit is crucial to acquire new technology and there by to augment total factor productivity. Bank lending promotes growth both through an increase in investment and a productivity channel. The capital accumulation channel is especially important for lesser developed and growing countries, while the productivity channel is highly relevant for advanced economies.

Saving and investment are the engine of growth in traditional neo-classical theories. Savings transform immediately to investment and it is thought that finance affects growth primarily through capital investment (Papaioannou,2007). A separate section of theoretical models says that financial development may boost economic growth by augmenting human capital resources. Galor and Zeira (1993) found that income inequality and credit market resistances impede the economic growth, as no all citizens can invest in education. They argued thus that financial intermediation can spur growth by fostering human capital accumulation.

\section{LITERATURE REVIEW}

A wide body of literature is available on the broad empirical work with regard to the relationship between finance and economic growth. Largely, this task has been executed by Levine (1997) and King and Levine (1993). According to them, financial development has predictive power for potential growth and explain this result as evidence for a casual connection from financial development to growth. Though the literature relating to the role of financial development on economic growth has grown remarkably in recent time, research works that examine bank lending or access to private sector lending and how it affects the economic performance of industrial units or/and economic sectors have been eclipsed by the growing number of empirical research works that mainly give emphasis on financial growth and development. 
Nevertheless, private sector lending is one of the major indicators of financial development. For that reason, the literature on financ growth relationship are of crucial importance for the study on bank credit-growth nexus. King and Levine (1993) presented the evidence that the financial sector proxied by the GDP to bank private sector credit ratio affects economic growth and development mutually through the improvement of investment productivity and through bigger amount of investment. Financial system could impact positively on real economic performance by influencing the structure of saving (Bencivenga and Smith, 1991), providing information (Greenwood and Jovanovic, 1990), and influencing the span for loan ceiling (Boyd and Smith, 1997).

Schumpeter (1971) recognized banks' role in easing technological novelty through their mediator role. He argued that the role of bank of flowing resources from excessive sector to scarce sector has a crucial role in promoting growth. Several others such as Fry (1988), Shaw (1973), (Kinnon 1973), Adekanye (1986), King and Levine (1993), and Adeniyi (2006) have emphasized on the significance of credit to private sector to economic growth. Likewise studies by Gurley and Shaw (1967), Goldsmith (1969), Jayaratne and Strahan (1996), Beck et al.(2000), Kashyap \& Stein (2000), Beck et al (2003), Driscoll (2004) etc, found that financial development can boost economic growth by increasing saving, improving allocative efficiency of loanable fund, and promoting capital accumulation. According to them, properly developed financial markets are the necessary requirements for the overall economic development of less developed and the emerging economies. King and Levine (1993a) said that, in Europe, banking sector's development was not only linked to economic growth but was also a cause of long-term growth. Adekanye (1986) argued, by giving credit; banks are providing a great social service which leads to increase in production, capital investment and increasing living standard. Akpansung (2011) found that private sector credit impacts positively on economic growth in Nigeria. But, interest rate on lending impedes economic growth. Furthermore, that paper recommends the financial market development that provides more credit to private sector with minimal interest rate is necessary to stimulate economic growth. A low rate of expansion of the bank lending volume is not only a symptom of poor economic growth, rather it can also be one of the reasons (Bundesbank, 2005). Bayoumi and Melander (2008) found that a 2.5 percent decline in overall lending generated a decline in the level of GDP by 
around 1.5 percent. Dey and Flaherty (2005) examined the effect of bank credit and capital market liquidity on GDP growth. They found that banking development is significant determinant of GDP growth. However Koivu (2002) found that credit growth has not always been supportive and in some cases it may have led to a decline in growth rates. Murty et al (2012) by using multivariate Johansen co integration approach, examined the long run impact of the bank credit on economic growth of Ethiopia and found that bank lending to the private sector influences economic growth by means of its role in effective distribution of resources and internal capital accumulation. Thus the policy makers should focus attention on long term policies to boost economic growth, the development of modern banking sector so as to enhance domestic investment, which is supportive to augmenting output and hence promoting economic growth in the long run.

Financial sector has a crucial role in flowing savings into productive investment particularly in the conventional sectors of the economy. The banking sector is well recognized as a key conduit of financial intermediation in an economy. Access to credit enhances the productive capacity of businesses (Nzomi and Rutto, 2012). Private sector credit is considered as proxy of bank lending in many international studies. Beck \& Levine (2001) measure financial development in the form of bank lending to private sector divided by GDP. Also the endogenous growth theory sheds light on the role of finance on economic growth. Solow $(1956,1957)$ in his two factor neoclassical growth model has incorporated the role of credit. The supply of bank lending, both in terms of volume and in terms of lending standards put on loans to enterprises, have crucial impacts on economic activities. On the other hand, a change in growth of loan has a positive significant effect on GDP (Cappiello, Kadareja, and Sarensen, 2010). Likewise, financial services increase income of poor by extending the supply of financial services to which the poor has access. It will generate income growth for the poor, thereby having a direct impact on poverty reduction (Jalilian \& Kirkpatrick, 2001). The role of bank lending in transmission channel of monetary policy cannot be ignored. Monetary policy may affect real economic activity, and ultimately inflation, via its impact on the banking sector lending through a number of transmission channels (Brunner and Meltzer, 1963 \& Bernake, 1983). With a view to analyze the impact of bank lending economic growth in Nigeria, Mamman and Hashim (2014) applied multiple regression model: 
ISSN: 2362-1303 (Paper) | eISSN: 2362-1311(Online)

JOURNAL OF ADVANCED ACADEMIC RESEARCH (JAAR) October 2016

$\mathrm{Y}=\mathrm{b} 0+\mathrm{b} 1 \mathrm{x} 1+\mathrm{b} 2 \times 2+\mathrm{Ut}$

Where: $\mathrm{Y}=$ (estimated value of the dependent variable) economic growth as measured by real GDP growth, b0 = base constant, b1-b2 = regression coefficients, $\mathrm{x} 1=$ aggregate bank lending $\mathrm{x} 2=$ size of financial intermediaries, $\mathrm{Ut}=$ error term.

They concluded that the response of aggregate loans to monetary policy is robust in state banking markets where financially restricted banks possess more market share. On the other hand, there is little difference in the response of state output across the market share financially restricted banks, implying that the total elasticity of output to bank lending is very small, if not zero. They reached to the conclusion though small firms consider bank loans as special, they are not adequately special for the credit channel to be an important part of how monetary policy works.

Timsina (2014) examined the impact of commercial bank credit to private sector on the economic growth of Nepal from supply side angle. The study has used Johansen co-integration approach and Error Correction Model using the time series data for the period of 1975-2013. She found that bank credit to private sector has positive effects on the economic growth in Nepal but only in the long-run. However, in the short run, it has been observed a feedback effect of economic growth on private sector credit. Particularly, the growth in real private sector credit by 1 percentage point results in an increase in GDP by 0.40 percentage point in the long run. The empirical results show that, policy makers should emphasize on long-run policies in order to boost conomic growth, development of modern banking sector, effective financial market, as well as infrastructure so as to increase the private sector credit which is instrumental to promote growth in the long run.

A summary of literature reviewed on effects of bank lending on economic growth has been presented in table 1 .

Table 1: Summary of literature reviewed on effects of bank lending on economic growth

\begin{tabular}{|l|l|}
\hline Study & Major findings \\
\hline Schumpeter (1971) & $\begin{array}{l}\text { He identified banks' role in facilitating technological } \\
\text { innovation through their intermediary role. He said that the }\end{array}$ \\
\hline
\end{tabular}


ISSN: 2362-1303 (Paper) | eISSN: 2362-1311(Online)

JOURNAL OF ADVANCED ACADEMIC RESEARCH (JAAR) October 2016

\begin{tabular}{|c|c|}
\hline & $\begin{array}{l}\text { role of bank of flowing funds from surplus sector to deficient } \\
\text { sector plays crucial role in promoting growth. }\end{array}$ \\
\hline Kinnon (1973) & $\begin{array}{l}\text { All components of GDP need credit to grow. In the context } \\
\text { of performing the financial intermediation, banks are } \\
\text { generating economic growth by providing needed resources } \\
\text { for real investment. }\end{array}$ \\
\hline Adekanye (1986) & $\begin{array}{l}\text { By providing credit, banks are rendering a great social } \\
\text { service which results in a rise in capital investment, output } \\
\text { and uplifting living standard. }\end{array}$ \\
\hline Levine (1993) & $\begin{array}{l}\text { Bank credit provided to the private sector, affects economic } \\
\text { growth both through the improvement of investment } \\
\text { productivity (better allocation of capital) and through higher } \\
\text { investment level. }\end{array}$ \\
\hline $\begin{array}{lr}\text { Bencivenga } & \text { and } \\
\text { Smith, } & (1991), \\
\text { Greenwood } & \text { and } \\
\text { Jovanovic, } & (1990), \\
\text { Boyd and } & \text { Smith, } \\
(1997) . & \end{array}$ & $\begin{array}{l}\text { Financial system could impact positively on economic } \\
\text { activities by influence the structure of savings providing } \\
\text { information and affecting the scope for credit rationing. }\end{array}$ \\
\hline $\begin{array}{l}\text { King and Levine } \\
(1993) \text { and Levine } \\
(1997)\end{array}$ & $\begin{array}{l}\text { Financial development has predictive capacity for future } \\
\text { development and there is an evidence for a casual } \\
\text { relationship that run from financial development to } \\
\text { economic growth. }\end{array}$ \\
\hline $\begin{array}{l}\text { Bayoumi and } \\
\text { Melander (2008) }\end{array}$ & $\begin{array}{l}\text { A } 2.5 \text { percent reduction in overall credit resulted a decline } \\
\text { in the GDP by approximatel } 1.5 \text { percent. }\end{array}$ \\
\hline $\begin{array}{l}\text { Cappiello, Kadareja, } \\
\text { and Sarensen (2010). }\end{array}$ & $\begin{array}{l}\text { A change in loan growth has a decisive and statistically } \\
\text { significant impact on nominal GDP. }\end{array}$ \\
\hline Akpansung (2011) & $\begin{array}{l}\text { Credit to private sector affects positively on economic } \\
\text { growth in Nigeria. }\end{array}$ \\
\hline $\begin{array}{l}\text { Mamman and } \\
\text { Hashim (2014) }\end{array}$ & $\begin{array}{l}\text { The response of bank lending to monetary policy is robust } \\
\text { in state banking markets. }\end{array}$ \\
\hline Olusanya et al (2012) & $\begin{array}{l}\text { Bank lending behavior is greatly influenced by volume of } \\
\text { deposits (Vd), exchange rate (Fx), Investment Portfolio (Ip), } \\
\text { Interest rate (Ir), nominal GDP and Reserve ratio (Rr). }\end{array}$ \\
\hline Timsina (2014) & $\begin{array}{l}\text { More particularly, the increase in credit to private sector by } \\
1 \text { percentage point contributes to an increase in real GDP by } \\
0.40 \text { percentage point itn he long span of time. }\end{array}$ \\
\hline
\end{tabular}


ISSN: 2362-1303 (Paper) | eISSN: 2362-1311(Online)

JOURNAL OF ADVANCED ACADEMIC RESEARCH (JAAR) October 2016

\section{STATUS AND PATTERN OF BANK LENDING AND ECONOMIC GROWTH IN NEPAL}

\section{Structure and pattern of lending in selected Nepalese commercial banks}

Lending is key to bank business and it is the major source of profit. It is also important because, monetary instruments are being implemented by affecting bank lending. Therefore, the analysis of bank lending is of crucial importance. Table 2 shows the structure and pattern of lending in sample banks.

Table 2 shows that lending varied widely from one bank to another. Table shows that RBB has the highest average lending of Rs. 75774 million followed by ADBN (Rs. 72216 million), NIBL (Rs. 67033 million), NABIL (Rs. 66996 million), EBL (Rs. 54884 million), NBL (Rs. 53241 million), HBL (Rs. 53124 million), GBL (Rs. 49321 million), NIC (Rs. 42042 million), NSBI (Rs. 39667 million), SBL (Rs. 36382 million), MPL (Rs. 33770 million), PCBL (Rs. 33077 million), BOK (Rs. 31795 million), LXBL (Rs. 29414 million), CBL(Rs. 29095 million SCBN (Rs. 27986 million), SNBL (Rs. 27348 million), KBL (Rs. 27024 million), NMB (Rs. 26819 million), NBBL (Rs. 25440 million), NCC (Rs. 21268 million), LBL (Rs. 17240 million) and GRBL (Rs. 9566 million). The average lending computed across the year is fluctuated widely over a period of time. It increased from Rs. 4827 million in 1996/97 to Rs. 39605 million in 2015/16.

As per the table, total lending varies widely within the individual banks also. It increased from Rs. 14856 million in 1996 to Rs. 53241 million in 2015/16 for NBL, from Rs. 18405 million in 1996 to Rs. 75774 million in 2015/16 for RBB, from Rs. 4306 million to Rs. 66996 million for NABIL, from Rs. 1703 million to Rs. 67033 million for NIBL, from Rs. 3131 million to Rs. 27986 million for SCBNL, from Rs. 2891 million to Rs.53124 million for HBL, from Rs. 1177 million to Rs. 39667 million for NSBI, from Rs. 676 million to Rs. 25440 million for NBBL, from Rs. 49 million to Rs. 54884 million for EBL, from Rs. 1075 million to Rs. 31795 million for BOK.

Total lending increased from Rs. 297 million in 1997 to Rs. 21268 million in 2015 for NCC, from Rs. 472 million in 1999 to Rs. 17240 million in 2015 for LBL, from Rs. 481 million in 1999 to Rs. 42042 million in 2015 for NIC, from Rs. 499 million in 
2001 to Rs. 33770 million in 2015 for MPL, from Rs. 264 million in 2001 to Rs. 27024 million in 2015 for KBL, from Rs. 124 million in 2002 to Rs. 29414 million in 2015 for LXBL, from Rs. 629 million in 2003 to Rs. 36382 million in 2015 for SBL, from Rs. 34225 million in 2007 to Rs. 72216 million in 2015 for ADBN, from Rs. 2597 million in 2007 to Rs. 49321 million in 2015 for GBL, from Rs. 2047 million in 2007 to Rs. 29095 million in 2015 for CBL and from Rs. 5154 million in 2008 to Rs. 33077 million in 2015 for PCBL. Similarly, the total lending of SNBL increased from Rs. 4045 million to Rs. 27348 million during the period of 2008 and 2015, which increased from Rs. 3691 million to Rs. 9566 million for GRBL and from Rs. 2010 million to Rs. 26819 million for NMB. 


\section{Table 2: Pattern of lending of commercial banks from year 1996 to 2015}

(This table shows the total lending (in million Rs.) of 24 sample banks associated with 369 observations. The mean value measures the average lending of individual sample banks and all sample banks for particular year and standard deviation measures the variability in lending.)

\begin{tabular}{|c|c|c|c|c|c|c|c|c|c|c|c|c|c|c|c|c|c|c|c|c|c|c|}
\hline Bank & 1996 & 1997 & 1998 & 1999 & 2000 & 2001 & 2002 & 2003 & 2004 & 2005 & 2006 & 2007 & 2008 & 2009 & 2010 & 2011 & 2012 & 2013 & 2014 & 2015 & Mean & Std Der \\
\hline NBL & 14856 & 18069 & 19472 & 22395 & 22864 & 21729 & 20756 & 19078 & 19108 & 17456 & 12180 & 13378 & 15481 & 19261 & 25074 & 26638 & 29551 & 37844 & 41191 & 53241 & 23481 & 9933 \\
\hline RBB & 18405 & 18922 & 22405 & 26340 & 29141 & 28081 & 28184 & 27970 & 26514 & 28614 & 26864 & 25215 & 27354 & 31464 & 35617 & 36792 & 40346 & 48981 & 60792 & 75774 & 33189 & 13750 \\
\hline NABIL & 4306 & 4625 & 5295 & 5812 & 7324 & 8173 & 7072 & 7997 & 8635 & 11078 & 13021 & 15657 & 21515 & 27817 & 32903 & 38766 & 42732 & 47523 & 55830 & 66996 & 21654 & 18818 \\
\hline NIBL & 1703 & 1729 & 1678 & 1422 & 2071 & 2386 & 2693 & 5873 & 7174 & 10295 & 13007 & 17482 & 27146 & 36250 & 40690 & 41665 & 42510 & 47369 & 53093 & 67033 & 21163 & 20667 \\
\hline SCBNL & 3131 & 3582 & 4171 & 4693 & 4957 & 5839 & 5676 & 6029 & 6662 & 8214 & 8905 & 10538 & 13355 & 13119 & 15932 & 17698 & 18376 & 23126 & 26317 & 27986 & 11415 & 7587 \\
\hline $\mathrm{HBL}$ & 2891 & 3382 & 4276 & 5372 & 7423 & 8837 & 9674 & 10894 & 13082 & 13245 & 15516 & 17672 & 19985 & 25292 & 28977 & 31657 & 34283 & 39649 & 44400 & 53124 & 19481 & 14393 \\
\hline NSBI & 1177 & 1721 & 2415 & 2930 & 3560 & 4091 & 4529 & 4761 & 5491 & 6619 & 8060 & 9847 & 12575 & 15465 & 17887 & 21657 & 26404 & 29147 & 35061 & 39667 & 12653 & 11535 \\
\hline NBBL & 676 & 1200 & 1958 & 3259 & 4612 & 7022 & 7969 & 8363 & 9996 & 8740 & 9011 & 8303 & 8420 & 8508 & 8860 & 9944 & 10673 & 12920 & 18825 & 25440 & 8735 & 5585 \\
\hline EBL & 49 & 322 & 868 & 1355 & 2270 & 2964 & 3970 & 5031 & 6117 & 7914 & 10124 & 14059 & 18814 & 24366 & 28130 & 31535 & 36376 & 44008 & 47956 & 54884 & 17056 & 17242 \\
\hline BOK & 1075 & 1336 & 1282 & 1812 & 2995 & 4275 & 4840 & 4913 & 6050 & 6167 & 7525 & 9664 & 12693 & 14895 & 16847 & 17248 & 18064 & 21806 & 26974 & 31795 & 10613 & 8830 \\
\hline $\mathrm{NCC}$ & & 297 & 1272 & 1524 & 1937 & 2894 & 2937 & 3322 & 4418 & 5934 & 5837 & 5084 & 5085 & 7142 & 8373 & 9217 & 12868 & 15920 & 17846 & 21268 & 7009 & 5798 \\
\hline LBL & & & & 472 & 922 & 1793 & 2295 & 2627 & 3207 & 3817 & 4315 & 4938 & 5366 & 5680 & 5480 & 6211 & 6979 & 9175 & 14247 & 17240 & 5574 & 4331 \\
\hline NIC & & & & 481 & 1659 & 2573 & 2329 & 2528 & 3729 & 4895 & 6883 & 9108 & 11447 & 13889 & 12906 & 15149 & 17460 & 32241 & 37301 & 42042 & 12742 & 12491 \\
\hline MPL & & & & & & 499 & 681 & 1494 & 2542 & 5051 & 6033 & 7281 & 8881 & 12957 & 14934 & 14711 & 16023 & 21634 & 29220 & 33770 & 11714 & 9904 \\
\hline KBL & & & & & & 264 & 1120 & 2144 & 3709 & 5519 & 6918 & 9011 & 11449 & 14682 & 14875 & 14898 & 17809 & 20083 & 22797 & 27024 & 11487 & 8001 \\
\hline LXBL & & & & & & & 124 & 764 & 1701 & 2701 & 4274 & 6528 & 9784 & 13446 & 14732 & 15263 & 15848 & 19143 & 21865 & 29414 & 11113 & 8577 \\
\hline SBL & & & & & & & & 629 & 1568 & 2635 & 3869 & 6320 & 9481 & 13505 & 16859 & 18398 & 20115 & 37844 & 27577 & 36382 & 15014 & 12248 \\
\hline ADBN & & & & & & & & & & & & 34225 & 36585 & 38271 & 39375 & 40389 & 45338 & 54959 & 62455 & 72216 & 47090 & 12429 \\
\hline GBL & & & & & & & & & & & & 2597 & 5058 & 9149 & 12139 & 12762 & 20410 & 26832 & 42555 & 49321 & 20091 & 15539 \\
\hline CBL & & & & & & & & & & & & 2047 & 4788 & 8196 & 10906 & 12437 & 14326 & 17684 & 23106 & 29095 & 13620 & 8142 \\
\hline PCBL & & & & & & & & & & & & & 5154 & 9817 & 14102 & 17070 & 19160 & 21736 & 27815 & 33077 & 18491 & 8552 \\
\hline SNBL & & & & & & & & & & & & & 4045 & 8907 & 12147 & 12369 & 14597 & 18335 & 20846 & 27348 & 14824 & 6800 \\
\hline GRBL & & & & & & & & & & & & & 3691 & 6456 & 7501 & 9034 & 11382 & 14322 & 14677 & 9566 & 9578 & 3549 \\
\hline NMB & & & & & & & & & & & & & 2010 & 5010 & 7508 & 10815 & 11135 & 15880 & 20135 & 26819 & 12414 & 7669 \\
\hline $\begin{array}{l}\text { Mean } \\
\text { Std Dev }\end{array}$ & 6404 & 802 & & 380 & $\begin{array}{r}7057 \\
8745\end{array}$ & $\begin{array}{l}6761 \\
7889\end{array}$ & & & 65 & 6402 & 5598 & & 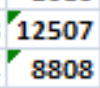 & 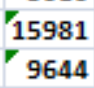 & & - & 11596 & 2025 & 8 & 18040 & & \\
\hline
\end{tabular}


ISSN: 2362-1303 (Paper) | eISSN: 2362-1311(Online)

JOURNAL OF ADVANCED ACADEMIC RESEARCH (JAAR) October 2016

(The figure shows the pattern of total lending for all sample banks from 1996 to 2015.

The figure has been drawn on the basis of the mean periodic lending).

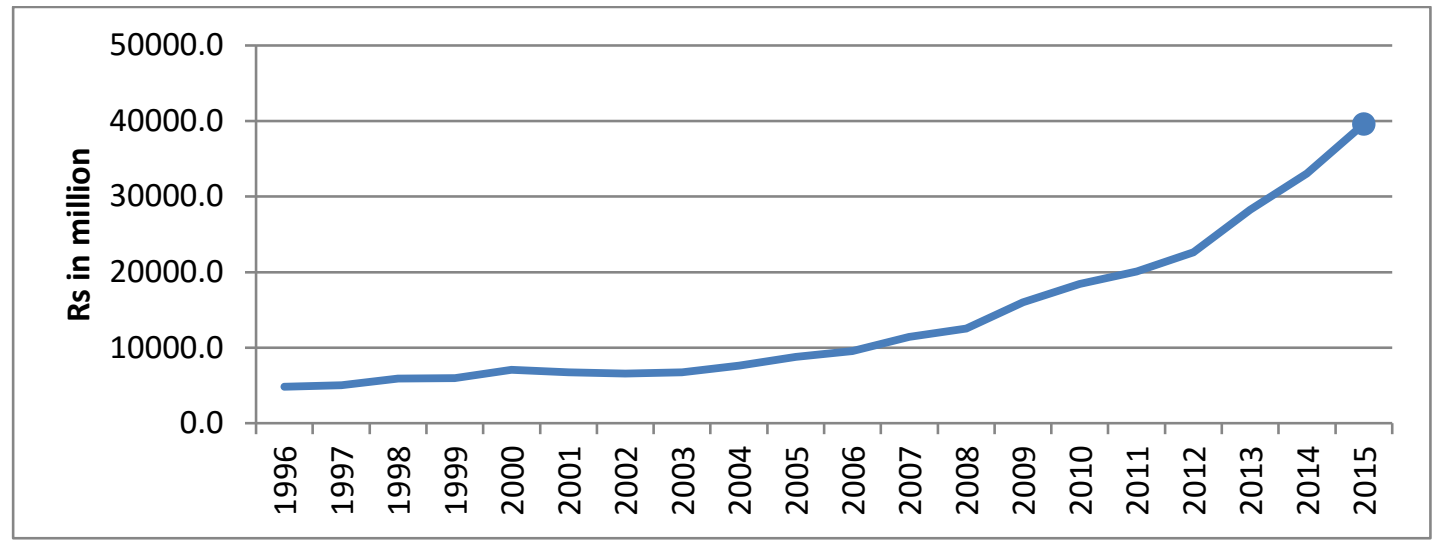

Figure 1: Pattern of lending of commercial banks from year 1996 to 2015

Figure indicates that total lending curve is in increasing trends until 2015/16. Moreover, average assets has been increased from Rs. 4827 million in 1996/97 to Rs. 39605 billion in 2015/16.

\section{Relationship between bank lending and economic growth.}

Figure 2 shows the positive effects of lending on gross domestic product. It indicates that increase in bank lending leads to an increase investment in various factors of production, technology and there by an increase in economic growth.

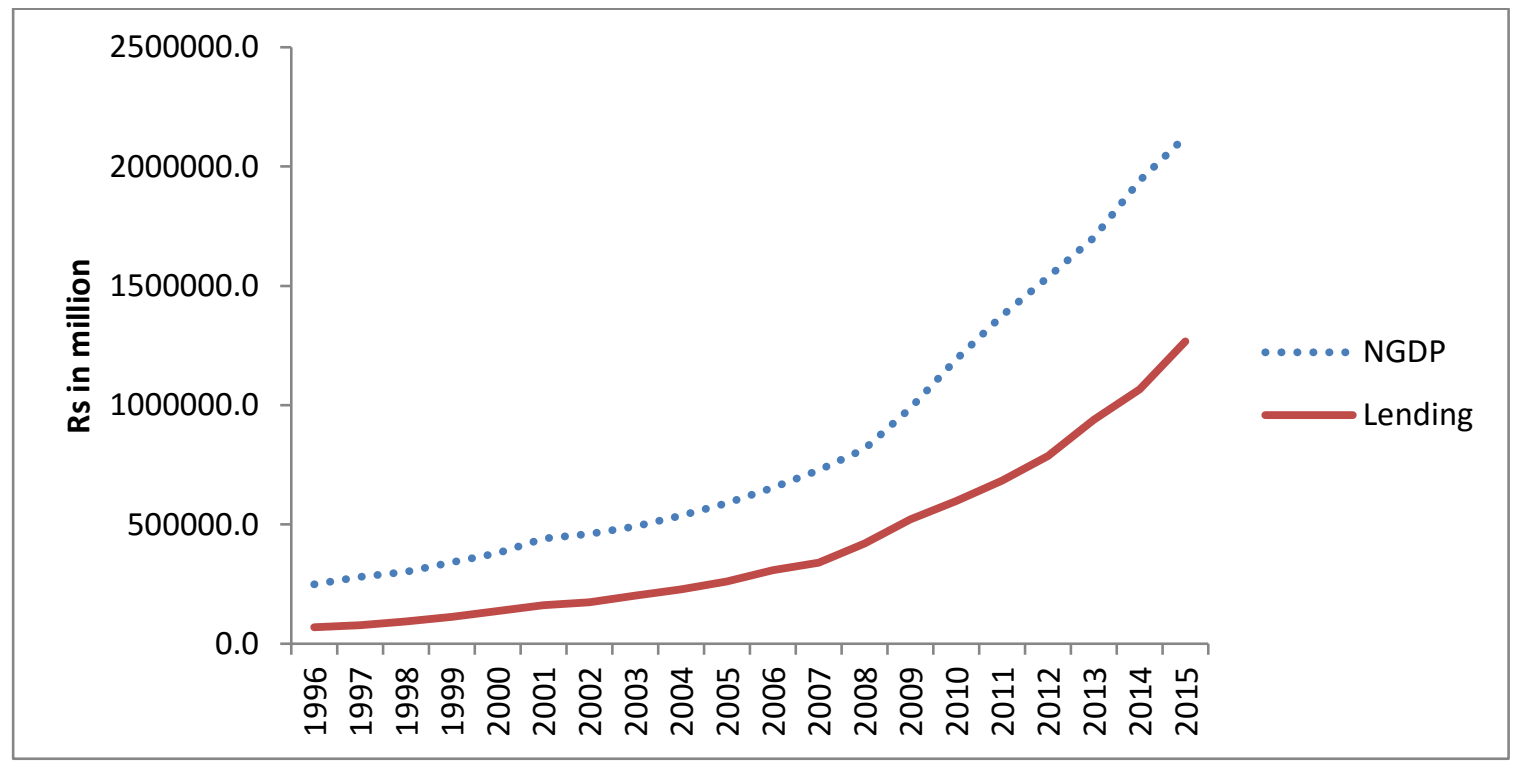

Figure 2: Relationship between bank lending and economic growth. 
ISSN: 2362-1303 (Paper) | eISSN: 2362-1311(Online)

JOURNAL OF ADVANCED ACADEMIC RESEARCH (JAAR) October 2016

\section{RESEARCH METHODOLOGY}

Research methodology sets out overall plan associated with the study. It provides a basic framework on which the study is based. Before presenting the analysis and interpretation of data, it is crucial that research methodology be explained first. In the absence of methodology, it is likely that the conclusions drawn may be misunderstood. This section therefore explains the methodology employed in this study with an aim to achieve the objectives of the study.

The study employs casual comparative research design in the sense that regression analysis was performed to estimate the relationship between the bank lending and economic growth on the basis of secondary data. It found the cause and effect linkage between bank lending and economic growth. Secondary data has been collected from 24 commercial banks for the period 1996/97-2015/16.

Description of the sample for secondary data in the form of number of observations and selected companies is presented in Table 2.

Table 2: Selection of commercial banks, period of study and number of observations

\begin{tabular}{|l|l|l|c|}
\hline S.N. & Name of banks & Study period & Observations \\
\hline 1 & NBL & $1996 / 97-2015 / 16$ & 20 \\
\hline 2 & RBBL & $1996 / 97-2015 / 16$ & 20 \\
\hline 3 & NABIL & $1996 / 97-2015 / 16$ & 20 \\
\hline 4 & NIBL & $1996 / 97-2015 / 16$ & 20 \\
\hline 5 & SCBNL & $1996 / 97-2015 / 16$ & 20 \\
\hline 6 & HBL & $1996 / 97-2015 / 16$ & 20 \\
\hline 7 & NSBL & $1996 / 97-2015 / 16$ & 20 \\
\hline 8 & NBBL & $1996 / 97-2015 / 16$ & 20 \\
\hline 9 & EBL & $1996 / 97-2015 / 16$ & 20 \\
\hline 10 & BOKL & $1996 / 97-2015 / 16$ & 20 \\
\hline 11 & NCCBL & $1997 / 98-2015 / 16$ & 19 \\
\hline 12 & LBL & $1998 / 99-2015 / 16$ & 17 \\
\hline 13 & NICABL & $1998 / 99-2015 / 16$ & 17 \\
\hline 14 & MBL & $2000 / 01-2015 / 16$ & 15 \\
\hline 15 & KBL & $2000 / 01-2015 / 16$ & 15 \\
\hline 16 & LXBL & $2001 / 02-2015 / 16$ & 14 \\
\hline 17 & SBL & $2002 / 03-2015 / 16$ & 13 \\
\hline 18 & ADBNL & $2007 / 08-2015 / 16$ & 9 \\
\hline 19 & GBL & $2007 / 08-2015 / 16$ & 9 \\
\hline
\end{tabular}


ISSN: 2362-1303 (Paper) | eISSN: 2362-1311(Online)

JOURNAL OF ADVANCED ACADEMIC RESEARCH (JAAR) October 2016

\begin{tabular}{|l|l|l|c|}
\hline 20 & CBL & $2007 / 08-2015 / 16$ & 9 \\
\hline 21 & PCBL & $2008 / 09-2015 / 16$ & 8 \\
\hline 22 & SBL & $2008 / 09-2015 / 16$ & 8 \\
\hline 23 & GRBL & $2008 / 09-2014 / 16$ & 8 \\
\hline 24 & NMBL & $2008 / 09-2015 / 16$ & 8 \\
\hline & Total number of observations & Up to 2015/16 & $\mathbf{3 6 9}$ \\
\hline
\end{tabular}

Source: Bank and Financial Statistics, Nepal Rastra Bank

Thus, the study is based on 369 observations.

\subsection{Type and sources of data}

The study is carried out in the area of commercial banks in Nepal and founded on secondary sources of statistics. The main sources of secondary data are Banking and Financial Statistics, Quarterly Economic Bulletin, Monetary Policies and NRB Directives published by Nepal Rastra Bank, and the annual report and website of 24 commercial banks (which are selected in the study) operating in Nepal. This study uses data of 24 commercial banks with 369 observations from 1996/97 to 2015/16. The relationship between dependent and explanatory variable are analyzed in through regression and correlation table. The statistical tool used for the study is SPSS.

\subsection{Models}

This study has estimated regression model to analyze the relationship between bank lending and economic growth. Hence bank lending is taken as the independent variable and economic growth is the dependent variable. From these independent and dependent variables, the following relationship is formulated. It is assumed that economic growth is dependent on bank lending It is represented as follows:

$$
\mathrm{GDP}=\mathrm{f}(\mathrm{L})
$$

Which shows lending is the function of monetary actions.

Where;

$\mathrm{L}=$ Lending

GDP $=$ Gross Domestic Product 
To study the relationship between monetary policies and the lending behaviors of commercial banks, the study used the following regression model in line with the conceptual framework.

\section{Model 1}

In model 2, the impact of bank lending is tested on economic variable (log of ngdp) with the help of regression estimates. The model is presented as:

$\operatorname{lngdp_{t}}=\beta_{0+} \beta_{1}$ lnlending $_{i t}+\beta_{2} \mathrm{IR}_{\mathrm{it}}+\mathrm{e}_{\mathrm{it}}$

where,

$\operatorname{lngdp}=\log$ of Gross Domestic Product

lnlending $=\log$ of bank lending

$\mathrm{IR}=$ Interest Rate

Interest rate is taken as the control variable in the model.

\subsection{Descriptive statistics}

This study has used summary of descriptive statistics associated with bank lending and economic growth during the sample period. The descriptive statistics such as mean, standard deviation minimum and maximum values have been used to describe the characteristics of bank lending and economic growth during the period of 1996/97 to $2015 / 16$.

\subsection{Correlation analysis}

Correlation analysis has been basically adopted to identify the direction and magnitude of relationship between bank lending and economic growth in this study. This relationship has been explained by using Pearson correlation coefficient. The value of correlation coefficient varies from -1 to 1 . The coefficient of correlation of exactly -1 indicates perfect negative correlation. On the other hand, the correlation coefficient of 1 indicates perfectly positive relation. 


\subsection{Regression analysis}

There are various assumptions of classical linear regression model. Some of the important assumptions are regarding the significance of regression coefficients as well as overall significance. This study has employed t-statistic to perform significance test of regression coefficients. In the language of significance test, a regression coefficient is said to be statistically significant if the critical P-value of test statistic is less than the level of significance specified. In other words, the statistical significance of the coefficient validates the explanatory power of associated independent variables. The levels of significance specified in this study are at 1 and 5 percent.

Besides, the statistical test of significance of individual regression coefficient, it is necessary to test the joint hypothesis that all regression coefficients are simultaneously significant. This is called the test of overall significance of the model. This can be done by using adjusted coefficient of determination (Adj. $\left.R^{2}\right)$ and F-statistic. The Adj. $R^{2}$ has been used to identify the percentage of total variation in dependent variable that has been explained jointly by all explanatory variables. The statistical significance of this joint explanatory power has been conducted by using F-statistics. The p-value of F-test has been examined to confirm whether the regression models are significant at 1 and 5 percent level.

\section{RESULTS}

\subsection{Descriptive statistics}

The descriptive statistics of different variables selected under the study are shown in table 3. Total lending of sample banks ranged from Rs. 49 million to Rs. 75774 million having an average of Rs. 15994.10 million. Likewise, IR has a minimum value of 4 percent and maximum value of 10 percent leading to the average of 5.83 percent. Average NGDP in Nepal was Rs. 990865.48 million with a minimum value of Rs. 248913 million and maximum value of Rs. 2124650 million.

\section{Table 3: Descriptive statistics for the selected variables under the study}


ISSN: 2362-1303 (Paper) | eISSN: 2362-1311(Online)

JOURNAL OF ADVANCED ACADEMIC RESEARCH (JAAR) October 2016

Table 3 shows descriptive statistics - mean, standard deviation, minimum and maximum values variables associated with 24 sample banks for the period 1996/97 to $2015 / 16$.

\begin{tabular}{|l|c|c|c|c|c|}
\hline \multicolumn{7}{|c|}{ Descriptive statistics } \\
\hline Variables & $\mathrm{N}$ & Minimum & Maximum & Mean & Std. Deviation \\
\hline Lending (Rs in millions) & 369 & 49 & 75774 & 15994.10 & 14446.71 \\
\hline IR (percent) & 369 & 4 & 10 & 5.83 & 2.008 \\
\hline NGDP ( Rs in millions) & 369 & 248913 & 2124650 & 990865.48 & 586296.99 \\
\hline
\end{tabular}

\subsection{Correlation analysis}

This section of the study presents the results and discussions of the correlation analysis. The correlation analysis has been carried out to assess the direction and amplitude of the relationship of monetary, bank specific and macroeconomic variables of the banks.

Having indicated the descriptive statistics, the Pearson correlation coefficients have been computed and the results are presented in the table 4.9

\section{Table 4: Pearson's correlation matrix for the dependent and independent} variables during the period $1996 / 97$ to $2015 / 16$.

This table reveals the Pearson correlation coefficients between different dependent and independent variables (Lending, Ir and NGDP]. The correlation coefficients are based on the data from 369 observations for the period 1996/97 to 2015/16.

\begin{tabular}{|c|c|c|c|}
\hline Variables & Lending & NGDP & IR \\
\hline Lending & 1 & & \\
\hline NGDP & $0.664^{* *}$ & 1 & \\
\hline IR & $-0.117^{*}$ & $-0.189^{* * *}$ & 1 \\
\hline
\end{tabular}

The table shows that there is positive relationship between bank lending and economic growth but negative relationship with interest rate which indicates that higher the bank 
ISSN: 2362-1303 (Paper) | eISSN: 2362-1311(Online)

JOURNAL OF ADVANCED ACADEMIC RESEARCH (JAAR) October 2016

lending, higher would be the economic growth in the country. This finding is consistent with Levine (1993), Bayoumi and Melander (2008), Bencivenga and Smith (1991), Greenwood and Jovanovic (1990), Boyd and Smith (1997), Cappiello, Kadareja, and Sarensen (2010), Akpansung (2011), Timsina (2014), Antzoulatos (1996) and Ludvigson (1999), Antzoulatos (1996) and Ludvigson (1999), Huang and Xu (1999) and Corsetti et al. (1999), Debelle (2004), and S.Yunus (2004).

\subsection{Regression analysis}

\section{Table 5: Regression of bank lending on economic growth (NGDP)}

The results are based on panel data of 24 commercial banks with 369 observations for the period of 1996 to 2015 by using linear regression model. Economic growth (log of NGDP) is the dependent variable while, log of bank lending and interest rate are the independent variables. The model is: $\operatorname{lng} d p_{t}=\beta_{0}+\beta_{1}$ lnlending $_{i t}+\beta_{2} I R_{i t}+$ error.

\begin{tabular}{|l|l|l|l|l|l|l|l|}
\hline \multirow{2}{*}{ Models } & \multirow{2}{*}{ Intercept } & \multicolumn{2}{|c|}{$\begin{array}{r}\text { Regression Coefficients } \\
\text { of Ingdp }\end{array}$} & Adj R $^{2}$ & SEE & F & DW \\
\cline { 2 - 8 } & Inlending & \multicolumn{1}{|c|}{ IR } & & & & \\
\hline 1 & $\begin{array}{l}4.34 \\
(53.81) * *\end{array}$ & $\begin{array}{l}0.39 \\
(19.54) * *\end{array}$ & & 0.51 & 0.19 & 381.87 & 0.59 \\
\hline 2 & $\begin{array}{l}6.22 \\
(154.09) * *\end{array}$ & $\begin{array}{l}-0.05 \\
(-8.11) * *\end{array}$ & 0.15 & 0.25 & 65.73 & 0.007 \\
\hline 3 & $\begin{array}{l}4.63 \\
(49.83) * *\end{array}$ & $\begin{array}{l}0.36 \\
(17.96) * *\end{array}$ & $\begin{array}{l}-0.03 \\
(-5.65) * *\end{array}$ & 0.55 & 0.19 & 222.94 & 0.55 \\
\hline
\end{tabular}

1. Figures in parentheses are t-values.

2. The asterisk (**), (*) sign indicates that results are significant at 0.01 and 0.05 level of significance respectively.

3. Dependent variable is log of NGDP (lngdp)

Table 5 shows that there is positive impact of bank lending on economic growth that indicates that higher the bank lending, higher the economic growth. It is because higher bank lending leads to higher investment in factor of production and technology and thus results in higher production. This finding is consistent with the findings of with Levine (1993), Bayoumi and Melander (2008), Bencivenga and Smith (1991), Greenwood and Jovanovic (1990), Boyd and Smith (1997), Cappiello, Kadareja, and 
ISSN: 2362-1303 (Paper) | eISSN: 2362-1311(Online)

JOURNAL OF ADVANCED ACADEMIC RESEARCH (JAAR) October 2016

Sarensen (2010), Akpansung (2011), Timsina (2014), Antzoulatos (1996) and Ludvigson (1999), Antzoulatos (1996) and Ludvigson (1999), Huang and Xu (1999) and Corsetti et al. (1999), Debelle (2004), and S.Yunus (2004). On the other hand, interest rate has negative impact on economic growth, as it discourages demand for loan and investment and thereby results in low production and low economic growth.

\section{CONCLUSION}

Bank lending is key to economic growth. Schumpeter (1971) identified banks' role in facilitating technological innovation through their intermediary role. He argued that the role of bank of channelizing resources from surplus sector to deficient sector plays crucial role in promoting growth. Several others such as (Kinnon 1973), Shaw (1973), Adekanye (1986), Fry (1988), King and Levine (1993), and Adeniyi (2006) have focused on the significance of bank lending to economic growth. The main objective of this study is to analyze the impact of bank lending on economic growth of Nepal. Though there are several studies that have been carried out on this topic in foreign countries but in case of Nepal there are not enough studies on this topic especially based on recent panel data and method. Thus, this study has fulfilled such gap in Nepal. The study has used 369 observations from the year 1996 to 2015 of 24 sample banks. It has conducted correlation, regression analysis under SPSS 20 to get the results.

The study concludes that bank lending has positive impact on economic growth but degree of explanation was quite low. This finding is consistent with the finding of Timsina (2014). The study implies that the policy makers should focus their attention more on the development of formal sector financing, adequate development of modern banking sector, development of efficient financial market and infrastructures and establishment of interest sensitive investment environment to increase the bank lending which is instrumental to promote economic growth in Nepal. 


\section{REFERENCES}

1. Adedoyin and Sobodun 1996 "Commercial Banks Lending Activities in Nigeria", Nigerian Financial Review,9(3): 36 - 37

2. Adekanye F. (1986). Elements of Banking in Nigeria, F and A Publishers.

3. Akpansung A.O. and S.J. Babalola(2011), "Banking Sector Credit and Economic Growth in Nigeria: An Empirical Investigation" CBN Journal of Applied Statistics Vol. 2 No. 2.

4. Basyal, T.R. (2009). Role of Finance - Nepal's Relative Position in the Private Sector Credit. Socio-Economic Development Panorama, Vol 1, No 4, July.

5. Bayoumi, T. \& Melander, O. (2008), "Credit Matters: Empirical Evidence on US Macro Financial Linkages" IMF Working Paper.

6. Beck, T. and R. Levine (2001), Stock Markets, Banks and Growth Correlation or Causality, Washington: The World Bank.

7. Bencivenga, V. and Smith,B.(1991),"Financial Intermediation and Endogenous Growth", The Review of Economic Studies, 58, 195-209.

8. Boyd, John H., and B.D. Smith (1997).Capital Market Imperfections, International Credit Market, and Non -convergence. Journal of Economic Theory, 73:335-64.

9. Bundesbank(2005),Credit Growth, Bank Capital and Economic Activity, Deutche Bundesbank Monthly Report, March 2005.

10. Cappiello, L., A.Kadareja, and C.K.Sarensen (2010), Do Bank Loans and Credit Standards Have An Effect on Output?Working Paper Series No 50, European Central Bank, January.

11. Dey, Malay K. and Flaherty, Susan (2005), "Stock Exchange Liquidity, Bank Credit and Economic Growth". Paper presented at the Max Fry Conference on Finance and Development, University of Birmingham, The Business School University House, Birmingham B15 2TT.

12. Fitz Gerald, V. (2006). Financial Development and Economic Growth: A Critical View. Background Paper for World Economic and Social Survey.

13. Galor, O. and J.Zeira (1993),"Income Distribution and Macroeconomics" The Review of Economic Studies, volume 60, No.1. 
14. Greenwood, J. and B. Jovanovic (1990), Financial Development, Growth and Income Distribution, Journal of Political Economy, 98:1076-1107.

15. Hashim, Y. and A. Mamman (2014). Impact of Bank Lending on Economic Growth in Nigeria. Research Journal of Finance and Accounting, Vol.5, No.18.

16. Jalilian, H. and Kirkpatrick, C; 2001, Financial Development and Poverty Reduction in Developing Countries, Working Paper No. 30, IDPM, Manchester University.

17. King, R.G, and R. Levine (1993), "Finance and Growth: Shumpeter Might Be Right". Quarterly Journal of Economics, 108, 717-738.

18. King, R.G, and R. Levine. (1993a). Financial Intermediation and Economic Development, In Mayer and Vives(Eds): Financial Intermediation in the Construction of Europe. London Centre for Economic Policy Research: 156189.

19. Kinnon, M.C. (1973). Money and Capital in Economic Development, Washington: The Brooking Institute.

20. Koivu, T. (2002), Do efficient banking sectors accelerate economic growth in transition Countries, Bank of Finland, Institute for Economies in Transition, BOFIT Discussion Papers 14.

21. Levine, R. (1997), Financial Development and Economic Growth: Views and Agenda. Journal of Economic Literature, 35: 688-726.

22. Mankiw, Gl, D. Romer and D.N. Weil. (1992). A Contribution to Empirics of Economic Growth. Quarterly Journal of Economics, May 107(2):407-437.

23. Mishra, P.K., K.B.Das and B.B.Pradhan 2009"Credit Market Development and Economic Growth in India"Middle Eastern Finance and Economics.

24. Okyo, M. Ifeoma, M. Blessing and U.D. Okelue 2012"The Effect of Deposit Money Banks Credit on Nigerian Economic Growth" International Journal of Current Research.

25. Olokoyo, F.O. (2011). Determinants of Commercial Banks' Lending Behavior in Nigeria. International Journal of Financial Research, 2 (2).

26. Papaioannou,E. (2007), "Finance and Growth A Macroeconomic Assessment of The Evidence From A European Angle"European Central Bank, Working Paper Series, No. 787,July. 
27. Romer, C. D., and Romer D. H. (2000). New Evidence on the Monetary Transmission Mechanism. Brookings Papers on Economic Activity, 1, 149-213.

28. Schumpeter, J.A. (1911). The Theory of Economic Development, Oxford: Oxford University Press.

29. Solow, R.M. (1956), "A Contribution to the Theory of Economic Growth". Quarterly Journal of Economics, 70. Pp 65-94.

30. Timsina, N. (2014). Bank and Economic Growth in Nepal: An Empirical Analysis. The NRB Economic Review, Vol 26, No.2. 